\title{
In the shadow of Apartheid: intergenerational transmission of Black parental trauma as it emerges in the analytical space of inter-racial subjectivities
}

\author{
Zelda Gillian Knight \\ Department of Psychology, Faculty of Humanities, Auckland Park Campus, University of Johannesburg, Johannesburg, South Africa
}

\begin{abstract}
Using the construct of projective identification and integrating it with the body of literature on intergenerational transmission of unsymbolized parental trauma, I describe the case of an adult black South African woman called Sibulelo. It is suggested that Sibulelo has unconsciously identified with the disavowed parents and grandparents trauma that they suffered as a result of the system of Apartheid. Such trauma is expressed through her feelings of being dis-located in time and space, as if she is living outside of herself, unplugged from life, and living someone else's life. The paper details the unfolding therapeutic process in relation to my whiteness in the context of her blackness. This brings into sharp focus an exploration of black-white racialized transference-counter-transference matrix in the context of intergenerational trauma. It is a reflective paper and opens up my own counter-transference, thus foregrounding the notion of therapeutic inter-subjectivity. A further contribution to psychoanalytic theory concerns the role of recognition and being seen as a powerful process in facilitating the symbolization of trauma. In addition, if there is no interruption of the cycles of intergenerational trauma, and therefore no symbolization, it becomes an unconscious familial compulsion to repeat. Moreover, this therapy case highlights the idea that as a traumatised family living within a bruised culture of intergenerational transmission of trauma, such repetition of trauma becomes a cultural compulsion to repeat what has not been spoken or named.
\end{abstract}

Key words: Race; Projective identification; Intergenerational transmission of trauma; Apartheid; Black client.

\section{Introduction}

The study of the intergenerational transmission of parental trauma began in the 1960's when therapists en-

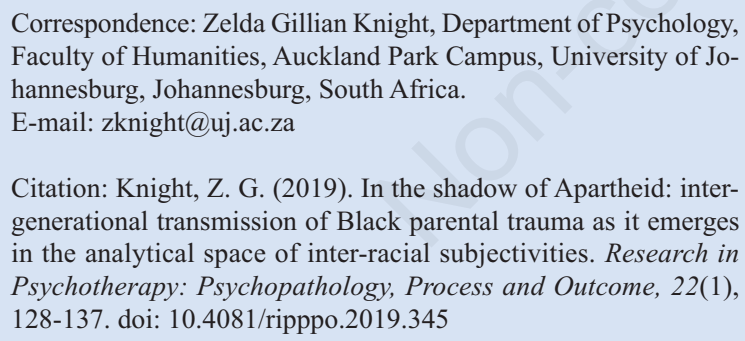

Citation: Knight, Z. G. (2019). In the shadow of Apartheid: intergenerational transmission of Black parental trauma as it emerges in the analytical space of inter-racial subjectivities. Research in Psychotherapy: Psychopathology, Process and Outcome, 22(1), 128-137. doi: 10.4081/ripppo.2019.345

Conflict of interest: the author declares no potential conflict of interest.

Funding: none.

Received for publication: 20 November 2018.

Accepted for publication: 10 January 2019.

This work is licensed under a Creative Commons Attribution NonCommercial 4.0 License (CC BY-NC 4.0).

CC Copyright Z.G. Knight, 2019

Licensee PAGEPress, Italy

Research in Psychotherapy:

Psychopathology, Process and Outcome 2019; 22:128-137

doi:10.4081/ripppo.2019.345 countered large numbers of children of Holocaust survivors needing help with mental problems and entering psychotherapy (Danieli, 1998). The concept of the transmission of intergenerational trauma refers to the notion that parents transfer their unprocessed trauma to their children (Feldman, 2015; Garon, 2004). The implication is that the children, as inheritors of this parental disavowal, continue to unconsciously experience life in the shadows of their parents' unprocessed pain and loss relating to their trauma (Brothers, 2014; Faimberg, 2005a, 2005b; Feldman, 2015; Garon, 2004; Knight, 2017; Matz, Vogel, Mattar \& Montenegro, 2015; Muhlegg, 2016; Roitman, 2017). Children not only unconsciously receive the parental disavowed trauma, but also unconsciously identify with it, perhaps throughout their lives (Knight, 2017; Muhlegg, 2016) thus ensuring the continuation of endless cycles of unresolved, intergenerational distress and trauma (Abraham \& Torok, 1994; Bartlett, 2017; Bohleber, 2007; Faimberg, 2005b; Feldman, 2015; Ferenczi, 1988; Garon, 2004; Knight, 2017; Muhlegg, 2016).

The intergenerational transmission of parental trauma research initially focused on Holocaust survivors only and their children (Abraham \& Torok, 1994; Anisfeld \& Richards, 2000; Bartlett, 2017; Bergman \& Jucovy, 2007; Bohleber, 2007; Brothers, 2014; Faimberg, 2005a, 2005b; Garon, 2004; Kestenberg, 1982; Kogan, 2002; Levine, 1982; Matz et al., 2015; Rapoport, 2011) but later was widened to include other traumatized populations including survivors of other genocides (Mangassarian, 2016; 
Vollhadt \& Bilewicz, 2013) as well as survivors of domestic violence (Matz et al., 2015).

There is a rapidly growing body of literature within psychoanalytic psychotherapy process depicting the emergence of intergenerational transmission of parental trauma (Abraham \& Torok, 1994; Bartlett, 2017; Bohleber, 2007; Faimberg, 2005b; Feldman, 2015; Garon, 2004; Knight, 2017; Muhlegg, 2016). For some individuals, trauma it is an opportunity for posttraumatic growth (Tedeschi \& Calhoun, 2004) while for others it renders life to living with a psychic hole (Kogan, 2002) a black hole (Eshel, 1998) or a dead third (Gerson, 2009). Feldman (2015) adopted Faimberg's (2005b) notion of telescoping of generations and described how the disavowed parental trauma in earlier generations captures and imprisons each new generation in an unbreakable net of unconscious, and therefore, unnamed and unwanted experiences. Feldman asserted that such transmission of intergenerational trauma, as family ghosts, often evade consciousness, and resist analytic attention while remaining a powerful haunting unconscious presence in the familial intergenerational unconscious.

Roitman (2017) maintained that when working with intergenerational traumatized patients, the therapist is subjected to depersonalizing states of dissociation from unmentalized, uncontained experiences of dehumanization, emotional numbness, and loss. He noted that when working with intergenerationally transmitted war trauma, it requires the therapist to address dissociative cocoons in the form of disorganized patterns of attachment (Roitman, 2017). According to Connolly (2011) therapy with these clients require a particular adaptation of analytical technique as what is important is not so much the analysis of the here and now of the transference and countertransference relationship, but the capacity of the analyst to recognise and accept the reality of the trauma with all its devastating and mind-shattering emotions without losing the capacity to imagine and to work with images that are essential if the patient is to be able to create a space for symbolization and representation.

An overarching research outcome of intergenerational transmission of trauma is that if left unprocessed and uninterrupted, it prolongs and perpetuates prejudice, hatred, violence, and the potential for continued conflict (Mangassarian, 2016; Matz, Vogel, Mattar \& Montenegro, 2015; Vollhadt \& Bilewicz, 2013).

Within psychoanalytic theory and therapy, the intergenerational transmission of parental disavowal has been linked to projective identification as a way to understand how this transmission happens (Knight, 2017; Muhlegg, 2016). Projective identification is viewed as the unconscious communication of a specific type of experience an unwanted emotional experience - from one person to another (Bion, 1962; Klein, 1946). Since Klein's (1946) early conceptualization of it as an intrapsychic process, it now includes both intrapsychic and interpersonal elements (Feldman, 2015; Muhlegg, 2016; Ogden, 1979).
Projective identification manifests in the transferencecounter-transference relationship (Baranger \& Baranger, 2008; Bion, 1957, 1962; Grotstein, 1981, 2005; Ogden, 1979, 1986; Racker, 1957; Searles, 1979). With the socalled relational turn towards the interpersonal in psychoanalytic theory and practice (Aron, 1996) projective identification has become a useful analytical process for understanding and interpreting clients' experiences (Bion, 1962; Goldstein, 1991; Grotstein, 1981, 2005; Muhlegg, 2016; Ogden, 1986; Racker, 1957; Spillius \& O'Shaughnessy, 2012; Zinner \& Shapiro, 1972).

While there is a mushrooming of psychotherapy case material on intergenerational transmission of parental disavowal and its link to projective identification, it appears that very little has been documented on an analytical process that describes: i) the emergence of intergenerational transmission of Black South African trauma, rooted in the Apartheid regime, and when, ii) the two people working together in the same therapeutic space are a black client and a white therapist. A black client and a white therapist in South Africa represent the historical racial division between Black and White populations during the notorious Apartheid regime in South Africa, prior to 1994. When a therapeutic space comprises this constellation, how does the therapeutic process unfold when the black client, a survivor of the brutal and brutalising regime, confronts her racial pain in the presence of a white therapist? Perhaps such a painful confrontation takes its particular shape and form because of the black-white inter-racial character of the transference-counter-transference matrix. Less so is written about such intergenerational transmission of Black trauma when it manifests through the mechanism of projective identification.

\section{What this paper is about}

The primary aim of this paper is to present a psychoanalytic psychotherapy case that explores the experience of a black South African adult female client, who shall be referred to as Sibulelo (all identifying data related to the client have been disguised. In some places, aspects of other thematically similar cases have been inserted so as to further camouflage any identifying details).

Sibulelo presents concerns that are rooted in intergenerational transmission of parental trauma. The trauma is linked to the atrocities of the Apartheid regime in South Africa prior to 1994. The paper details the unfolding drama of the therapy process in relation to me, as the therapist, and my whiteness. By implication, it is relational in approach, reflexive, and explores the development of analytic material that may not have developed had the therapist also been black. It thus brings forth and foregrounds the racialized transference-counter-transference matrix. As such, the paper incorporates my subjectivity as counter-transference, and how this brings about certain layers of conscious and unconscious experiences for both client and myself. 
This paper is not a commentary on the past politics of South Africa nor the system of Apartheid; these form the backdrop of the case but are not the focus.

\section{The case of Sibulelo}

My client, Sibulelo, 54 years old, described herself as a modern kind of African woman living and working in a big modern city, going to shopping malls decked with international designer names, such as Prada, Gucci, Kate Spade, travelling for holidays overseas to luxurious destinations, driving her BMW to the middle-upper class leafy-green suburbs populated mostly by high earning and affluent black South Africans, dropping off the children at expensive private schools, and meeting with friends in French cafes for coffee to chat and discuss the latest news and views depicted on international television channels beamed into her home via fast internet connections and Wi Fi access. She has a full-time maid, and a gardening service. She works full-time in top level management. She is divorced, has two children, and her parents stay with her in her six-bedroomed home.

Sibulelo is no ordinary black woman. She is rich, lives and works in a major city in South Africa where most black people are poor, own very little, and live in small brick or shanty houses in the townships. Unlike most of the black people, she has access to private psychotherapy, medical insurance, and a high standard of physical and mental health care.

\section{A black client choses a white therapist: racializing the therapeutic encounter}

She tells me at the start of our first session that she chose me because she had heard about me from her black friends who had also been in therapy with me. They had described me to her as a whitie [a colloquial, non-derogatory term for a white person] with a difference. Despite there being other qualified black therapists available in the city, it is thus significant that she chose me, a white therapist, and thus, she initiated a racialized encounter from the very beginning. This black-white therapeutic space set up by her makes me sensitive to, and more aware of, what may occur because I am white.

I was soon to realize that it is only our age that mirror our joint analytical engagement. I did not have her rich lifestyle, nor could I relate to having children and the socalled school-run, nor could I relate to her high-powered, high salaried position in a competitive corporate environment. I had only ever worked in a university context with a much lower salary, and as a part-time private practitioner. Her reference to my whiteness so early in the session surprises because it is now 24 years post-apartheid, and thus issues of race in therapy, in my experience, are now minimal. Maybe I am naive. As she sits down on my red puffy couch, puts her expensive Polo handbag to one side, I ask her "What do you mean by whitie with a difference?". I thus engage her race-talk directly. She replies that she heard black people can speak to me about things of the past, and not feel that I will get all defensive and hostile.

I realise that she will possibly want to talk about things of the past, more specifically, talk of the black-white past. I am open to this, and have done some work with black clients on black-white race matters (Knight, 2013). The rumour apparently was that other whities get defensive and hostile, but not me. This is my difference. To her friends, I am non-hostile and undefended. I wonder, however, as she sits across from with me, if I will fail her and become defensive. I wonder what is going to manifest in the space between us. I feel excited and, at the same time, I feel an unnerving dread.

In our first encounter, I realize that I like her, perhaps because she is so different to me. Perhaps I feel a narcissistic pleasure that I was chosen. She presents herself to me as a rich woman with her high heels, expensive designer dress, red lipstick, and false eye-lashers, She is not $m e$ in that I sit with my baggy Yoga-like pants, soft simple cotton shirt, flat heeled shoes, blonde highlighted greying pixie cut hair, and no make-up. I am essentially the hippie, and she, the modern urbanised African woman, poised to get up and go. At first, I wonder about my hippie-ness in the stark contrast to her moneyed look. Perhaps this additional difference will be essential to the process.

\section{Living someone else's life}

I cannot imagine what might bring her to therapy because she looks so well put-together and dressed up. She must have taken hours to get dressed, and put on the perfect make-up and matching Gucci shoes. However, appearance is never what it seems. I invite her to tell me what brings her to therapy. She begins to speak about her sense of feeling dis-located in time and space, as if she is living outside of herself. She feels her life had taken on a shape and form she cannot understand, as if she is unplugged from the flow of life, and living someone else's life.

I am aware that I have been feeling, and still am feeling, dis-connected from colleagues and the usual buzz of work. I like her word, unplugged and it resonates with me. I wonder if she is unconsciously picking up something of my mental state. As she speaks, I am aware that I am also missing my best friend and colleague, who has recently immigrated. I feel sad as I think about her. The sound of Sibulelo speaking again brings me back to our here-andnow moments. In these kinds of situations of reverie and the emergence of the analytic third (Benjamin, 2004; Ogden, 1997) maybe she too was feeling not only unplugged but also sad, thus bringing more layers of our inter-subjectivities into the room and into the analytic space. Ogden (1997, 2004), following Bion (1962) argues that reverie may be defined as the analyst's capacity to pay careful attention to the most narcissistic preoccupations, ruminations, and daydreaming fantasies, which, in 
the intersubjective field, may help the analyst to better understand what is happening unconsciously to the patient. These preoccupations are always co-created analytic objects, or the analytic third, and thus co-created by the shared, collective unconscious dynamic in the therapy process (Ogden, 1997; 2004).

I take note of her feelings and my own feelings, and how the analytic third has developed and what form it has taken. I wonder too if she is feeling dis-connected from me. I am brought out of my reverie as she tells me she feels that there is a dead thing inside her. Using her own words, I ask her to describe this dead thing. She says it is an ugly creature-like figure. She describes it as a kind of malformed human foetus but with a deformed lizard-like head. As she continues to speak about this dead, unwanted creature that is lodging itself inside her, I wonder if her dead thing and also sense of being unplugged from the flow of life has anything to do with a past trauma. In my experience, descriptions of dead things inside one are often linked to an unspoken, often repressed trauma.

Conscious of my own thoughts, and what she has just said, I ask her what she feels. She replies that she is not sure. Maybe it is sadness. I remember I had just been feeling sadness too. Did she pick this up from me, or did I from her? In my experience, the analytic third is not a mirroring of content as much as emotional processes. She stops talking for a while. I sense that something is blocking her. I don't know where this sense of blocking comes from. I am about to act on my counter-transference and ask her if she is experiencing some kind of block, a blocking of the full expression of sadness. Before this happens, she speaks again. She says she became successful because her parents wanted her to. However, she also tells me they never actually told her to be successful, like osmosis or magic, it was just expected, and she did what was expected without questioning. She just picked it up from them. She shares her feeling again that she is living someone else's life. We explore this, and I wonder about my sense of something blocking her. I am feeling a bit lost, as if I was on a path but cannot find it anymore. We don't seem to be speaking, and it feels like the therapy process has become blocked. I am not sure what or who is doing the blocking. Has my sadness blocked her, blocked us? As I process this thought, she speaks about feeling that the dead thing is blocking her in moving ahead with her life, in finding direction and being motivated. She again says she is living someone else's life, making this statement to be core to the process. I now also know she is experiencing something blocking her, a mirroring of my experience. It is not just me. Relational theory posits that things are never just me; analytic material is always cocreated (Aron, 1996). Ogden $(1997 ; 2004)$ reminds therapists that the analytic third, or the collective unconscious in the room, links the two subjectivities, is never solely an intrapsychic process; rather, it is the sharing experience between two subjects.
I asked her to tell me more about this dead thing. She speaks about it as her parental expectations of her. I wonder why parental expectations are experienced as a dead thing. I am trying to make sense of the dead thing, her sense of being blocked, the sadness, and I suddenly feel lost again. I am feeling tossed about like a leaf on a raging river. I don't know what is happening. I am feeling disconnected from her, or is it that she feels dis-connected from me. Is she being tossed too?

I plunged into the analytical waters that we share and offer a comment that living someone else's life must feel like being tossed about. She replies by agreeing to this comment. She also says that she feels like a leaf tossed about. She feels the same feelings as me. It is uncanny. I suddenly feel a connection to her once again, that the shared unconscious of being tossed about is bringing us together. In my excitement and relief of being connected again, I want to reach out to her but I am not sure that she feels the same way. I explore more her sense of being tossed, asking her to describe her feelings. Things take a turn, and she becomes angry. She feels out of control, and that the dead thing inside her is taking over her mind. I am alarmed at the turn of events. Have no time to process it, and go with what she presents.

\section{Black anger}

She turns this anger towards me, and she says, with a biting voice, that she never thought she would see a white person dress like me. She says I look like a white hippie, like white trash, and that my clothes don't really match, and my shoes are rather dull, and I should wear make-up. While I can hear the attack, criticism and the judgement, and the reference to me being a white hippie, and it seems this is not a good thing, I can also hear her reference to my whiteness as not acceptable to her in its current state.

I remember that she had said earlier that she had chosen me because I was $a$ whitie with a difference. What did my whiteness mean for her? Why the hostility? Is her judgement and hostility linked to my whiteness? I want to defend my casual dress code, but I don't. I feel unsure as to what is going on, and have the tossed feeling again. Is she feeling tossed about, and is this an unconscious communication from her? Is the anger from her something that I have triggered in her? How should I respond, if at all?

According to Winnicott (1971), infants' ability to become alive fully depends on the mother's ability to survive the infant's ruthlessness and on her capacity not to retaliate. The mother must hold and contain her pain at being attacked and any feelings of failure. She must recuperate which means process her pain, find new strength, and carry on. Her ability to continue on with her love and care means not retaliating, not seeking revenge or damaging the infant. The endless cycles of a child's ruthlessness together with maternal ability to survive and not retaliate create an area of faith in the on-going-ness and dependability of the mother (Eigen, 1981). The infant 
fragile psyche develops in this cocoon of an area of faith, and learns that there is no damage or destruction. In therapy, the same process occurs between therapist and client. The therapist becomes the object to be used (Winnicott, 1971) and does not retaliate to the client's ruthlessness.

My whiteness becomes an object for Sibulelo to use. If in being used, I feel attacked, I must not retaliate. Winnicott urges that I must be moulded by her, shaped and designed into what she needs, and survive. She needs to experience this area of faith and depend on my ability to recover. I do not immediately reply to her and her judgement about my dress style. I wait. I listen. I note that she had said she feels out of control, and that the dead thing inside her is taking over her mind. She had also mentioned earlier that she felt that she is living someone else's life, and this feels like she is being tossed about. I mention that maybe the feeling of a dead thing inside her mind makes her angry. In my practice, the experience of dead things inside a person takes over a part of them, and makes them feel angry, as if this kind of thing should not happen.

She replies and confirms that she feels anger about the dead thing inside her, making her feel that something is possessing her. She gets angry about this. She asks me how she can get rid of it. I reply that I am not sure what is needed but let's explore this together and maybe something will emerge around how to get rid of it.

She next talks angrily about her childhood. About her school years and growing up in the townships. About the bad whites and what they did. About the Apartheid years. She suddenly asks me how I feel about being a white person. She is inviting me to become more engaged in race. I cannot relate to growing up in a township, and thus to her childhood black experiences. She is perhaps unconsciously aware that I cannot relate to her experience, but despite this, or because of this, she is inviting me to take a deep dive into my whiteness. She has again foregrounded my whiteness. It had been there beforehand, but less spoken about. It is now a core part of our inter-subjectivity, and part of our difference. The difference separates us from each other, and yet, it brings her into the process with me, with her blackness and my whiteness. She had chosen me, knowing I was white, and a whitie with a difference. Her selection of my whiteness made her blackness an essential bedrock of the therapeutic experience. Her blackness and my whiteness irrevocably ushers in a racialized transference-counter-transference that exists in her mind even before we met. How do I feel about being a white person? Why ask my about my whiteness? What did my whiteness mean to her, and what did my feelings about my whiteness mean to her, and why did this matter to her, and to me? My reply would determine the texture and contours of our future black and white relationship.

I reply, "Why does this matter to you?"

Sibulelo shifts forward, leaning in, looking intensely at me, not letting me say more, and perhaps controlling me, as perhaps she could not control the dead thing inside her. She replies, "I am not sure why it matters, maybe it is nothing, and maybe it is everything. Nevertheless, you need to know something about me that I am not what you think you see.

This statement from her, I am not what you think you see sticks with me. It shifts things closer towards my whiteness and because of it, in her eyes, I am not seeing her, I have assumed things about her. What did I assume about her? I ask her what she thinks I see, drawing out the transference. She replies, "a rich, black woman", and I say, "what do you think I think about rich, black women?" She stops there. Maybe she does not want to know what I think. I don't push. She is irritated, wiggles in the sofa, stares at me. I feel she is wanting me to say something; I am not sure what to say. I wait. She stares at me. Then she says, "you think less of me because I am rich, have more than you, and I am black. You think black people should be poor, and you should be rich". I don't think this. I think, however, about this black assumption of my whiteness. Have I dismissed her blackness, or is it that she was dismissed in the past, not seen, and her blackness was dismissed in the past by whiteness, and not seen.

She continues in an angry voice, "I am a black woman with money, with cars, a big house, a woman who probably has more wealth than you, a bigger car than you, a better salary then you, in fact a lot of better things better and bigger than you, least of all a better dress-sense than you". As she is saying these things, she defines her difference in relation to being better than I am. I wonder why. Is she feeling better for saying these things? I sit and listen. She is angry. She glares at me. I feel her rage. I am not intimidated nor afraid of her anger. I reflect back to her that she is hurt, hurting, that something has happened to make her feel raw and sore inside.

How am I contributing to this development? I offer another comment and say to her; perhaps it is my whiteness that you want to lessen, perhaps it has hurt you in some way.

This is an important and pivotal moment in the process.

She says, suddenly having lost her anger, "I think maybe this is the case, I am hurting, but it is not about you". I reply, "I can see you are hurting". I know her anger is still there but it is in a lesser, sharper, biting form, and perhaps it is less because she has had some (white) recognition of her hurt and pain. The space between us coagulates into black and white talk about her feelings about white oppression and black pain. There seems to be no space for me. I am wedged out, but I am also a part of everything. She is upset. She asks me about my past, and in such questioning, I think she asks me about my white past in relation to her black pain, to Apartheid, to all black pain. If I say anything that looks like I am dodging some accountability, defending myself, defending my whiteness, I may be re-enacting a past event from her past pain. 
I ask her what she needs to know about me. I tell her I am open to providing any information she needs. My non-defensiveness shifts her away from wanting me to disclose and she begins to speak again about her own life as a child growing up in Apartheid.

\section{Haunted by memories of a dreadful past}

With this black-white dynamic rushing and roaring about the landscape of our therapy, forging out new territory for us both, carving out something new, things take a turn. She says she is different but also like so many black woman of her age who grew up under Apartheid.

As she says this statement, it makes a swivel in the trajectory of our journey. She proceeds to tell me that she is haunted by the memories of a dreadful past. She says she is also haunted by her parents, dreadful memories and by her grandparents' dreadful memories. She says that she thinks the dead thing inside her is the same as the deformed, lizard-like creature. It is all her parents dreadful memories that she feels have become stuck inside her body. The therapy process seems to take on a new energy as she speaks about how she could not ever get away from her memories, as well as the memories of her family. She begins to speak about the unspeakable trauma she suffered during the Apartheid regime. Every word she speaks seems to be grounded in my whiteness and in her blackness, and our racialized inter-subjectivity. She tells me childhood stories of pain, racism, humiliation, fear, and violence. Such stories are framed and etched out only because she was a black little girl living in a white world of domination and oppression.

While originally the dead thing was about parental expectation, and now it is the memories they have given her, it is not something different but the same story. It is the memories that have been internalised and the underlying message to her, rooted in these memories, is become successful so that these memories will mean something.

Tears run down her face. I reflect back how terrible this must have been. It is not easy listening. It is not easy to bear witness to trauma, and even less so when it spans generations. I feel her pain. I feel like I am dissociating, that something is leaking out. There are massive concrete dam walls of deep emotions that have broken open in her, and the deep pain gushes out in a fury and fiery wildness that floods every part of the therapy process, seeping into my bones. I feel I am drowning. I am soaked in her pain. I wonder if she is drowning too, and maybe she has put into $m e$ her feeling of drowning. I cannot not stop my own tears from trickling out. She cries, with snot and spittle dribbling down her face, and her voice becomes angry and loud. She shouts at me as she recalls memories of her childhood of fear of whites, of hatred for whites, her face oozing rage. She is submerged in her black history of angst and anxiety, deprivation and degradation. I am pulled under these dark waters of her pain to witness it all.

In order to become a stable, non-retaliating and secure supporting object for Sibulelo, I surrender to the process and let the thirdness between us develop (Benjamin, 2004, 2009). I let go. I don't try to stop my thoughts of being submerged. The surrender is a process of recognition: the ability to contain my separateness and difference while I remain connected to the other's mind (Benjamin, 2004, 2009). The third needs my surrender to evolve and shift onto other dimensions of collective unconscious. My mind and her mind begin to merge into that dual unconsciousness. She speaks of feeling that she is drowning, just as I am feeling. We have connected. It feels oddly safe. The room feels like it is underwater and we cannot breathe anymore, but we are in this together and I have the sense that we will survive. My reverie of this survival takes form in the unconscious communication, in the reciprocal process of projective identification. The drowning is a part of the analytic space, and defines us; it gives our inter-subjectivity a (watery) form. Out of this watery form, rooted in surrender to the process, she is able to breath, to come up to the surface, and continue on.

She tells me about her mother and father and stories of their Apartheid experiences. She says that her whole life she has heard both her mother's and father's pain about the days of Apartheid, and that it sit inside her. She speaks about how they told her of their fear, how they dodged bullets as children, how they feared the night-time township raids, how they hated the army tanks that rolled into their poor, unpaved and dusty streets, how they heard the cries and screams of people being arrested, bullied, and harassed. She tells me she stopped listening to the stories at one time, blocked them out, and tried to bury the stories of fear. As we speak, she makes the link to these buried and hidden stories of fear as the sense of living someone else's life, of being unplugged from her own life.

The intensely emotional and first session comes to a close. It has been a longer than usual session as is my custom for all first sessions. Normally I use the extra time for a brief clinical in-take interview, but not this time. Sibulelo is calm at the end of the session. She is ready to leave and gets up to go. She says she will make an appointment for next week before I mention this. I feel tearful again because maybe we are still connected, linked together by what has been happening to her. I feel still saturated by her powerful emotions, and particularly drenched in her pain and rage. I am soaked with my own feelings of being submerged in her emotional pain, and even in her absence, I feel plunged into places of my own unprocessed content of being white. In this emotionally water-logged experience, I think about her initial presenting feeling at the start of the session of living outside of herself, as if her life had taken on a shape and form she could not understand, unplugged from the flow of life, tossed like a leaf and moving along with no purpose.

I have stories of pain, but they are not like her stories. I have wept and gnashed my teeth against prejudice and racial victimization. I am not like most white people, as 
she first recognised, and perhaps she unconsciously recognised my own racial pain, allowing a space of trust to develop because of it, as if I would relate to her more because of it. I can relate, to some extent, to her frustration, anger, and fear, but at some level, I don't know, I will never know what is was like for her and her family.

I can merge into this black-white inter-subjective racialized cocoon of analytic space. She knows enough about me, and grounded in our shared analytic third, she is able to uncover deep pain and anger.

\section{The alien within}

In the following months, we return to the analytical material raised in this first pivotal session. We return to black trauma of Apartheid, to specifically her parents' trauma and appalling pain. She feels she has been living in the shadow of Apartheid, more accurately, in the shadows of her parents' pain. We talk about my whiteness in relation to her black pain. It seems that her pointing out my having less than her was a way to move into her own anger about whiteness, to dominate whiteness in making it less than. She needed this power over me, over my whiteness perhaps because in her mind I was still powerful because I was white.

Sibulelo uses her time to speak about her sense of being dis-located, unplugged from the flow of life, and narrates again her dreadful experiences of growing up in under the Apartheid regime. She makes sense of some of the experiences as not-me experiences. When the trauma is massive, prolonged and deliberately inflicted, "whole tracts of our being can plunge back into unconsciousness and vanish from the surface for years and decades" (Jung, 1934, para.286). The not-me experience is both a blocking out, dissociative experience plunging details and events of the trauma back into her unconscious. However, it is also more than that. For her it is a sense that something was inserted into her, put inside her by another person or persons, and it feels alien. It does not belong to her. She feels that she has been carrying this alien, unwanted, uninvited part of herself. She feels that the alien is not just her own trauma but also her parents' trauma.

Perhaps one of the earliest theorists on the transmission of parental trauma to the next generation is from psychoanalyst Ferenczi (1988). Ferenczi introduced the concept of the alien transplant which refers to a psychological process whereby unprocessed and thus disavowed parts of the parental traumatized psyche are inserted or transplanted into the child. Ferenczi emphasized that " ....these split-off alien transplants vegetate in the other person during their entire life" (3:81) and thus they are always present in some form or another. The alien transplant is not an add-on as in the case of an introjection, but it can be so intrusive as to replace what was there - be in place of some of the unconscious content already there. This perspective dramatizes how the transplant is an unwanted intrusion into the child's psyche, and as a projective identification, it pushes aside some of what is inside the child, thus transforming some of the structure of the child's psyche. The alien transplant cannot be separated from that of trauma, pointing to the idea that unprocessed trauma is transmitted to another as a way to manage the unspeakable.

Later she tells me about her more about her grandparents' experiences of Apartheid. They are heart-breaking stories. She does not cry but I feel my own tears well up. The grandparents don't speak much about their experience to her, and she has to get their stories from others in her family, mostly her parents. We come back to the sense of the unwanted alien within, linked to her not living her life, but somehow their lives; living in the shadows of their pain, haunted by their unsymbolised and unprocessed trauma.

Garon (2004) identified that the alien transplant, "is never so active as when it carries transgenerational traumas... and takes on its true meaning when we take into account what was silently and actively transmitted from one generation to the other" (p. 87). In further amplification of the idea of the alien transplant, Garon $(2004$, p. 88) observed that "the concept and the fate of the trans-generational alien transplant as well as the splitting that occurs over time as disavowal takes on different shapes and forms as it courses through the generations". To this end, Garon concentrated more on the different kinds of patterns of disavowal in each generation that emerged in terms of the transmission of trauma. The patterns of disavowal refer to "the first generation takes the shape of an object of negation, in the second, denial and in the third generation, family secrets can be foreclosed" (p. 88). Garon subsequently associates these three destinies of disavowal: (negation, denial and foreclosure) with three corresponding types of linguistic exclusions, i.e., the unspeakable, the unnameable, and the unthinkable (p. 88).

In relation to destinies of disavowal, Sibulelo's task is to symbolize the unsymbolized, become the healer of what was not healed (Faimberg, 2005b; Feldman, 2015; Ferenczi, 1988; Garon, 2004; Volkan, 1997) speak the unspeakable, name the unnameable, and think the unthinkable (Garon, 2004).

In the analytic inter-subjectivity, speaking, naming and thinking, and therefore, symbolizing intergenerational trauma is sometimes a drowning process. One can become submerged. It is a process of surrender, for both client and therapist.

She also tells me that she thinks the alien is largely the unspoken stories of the parents and grandparents which have been passed to her without her really knowing what was happening. Instead, she feels she has become rich and successful, as a way to defend against her own almost inexplicable anxieties of this alien taking control of her life and destroying it. She tells me she has felt anxious her whole life but cannot say what it is about. This life-long anxiety is possibly related to the transmission of the parental trauma in that it can pass on unprocessed parental 
anxiety related to the trauma. "When experiences of unsymbolized trauma through projective identification coalescence around lifelong experiences of inexplicable anxiety in the targeted child, it is suggested that this process can be described as the transmission of intergenerational traumatic anxiety (Knight, 2017, p. 125). Now she has some clue. For her, money is a shield against exploring her feelings. She feels she can go shopping instead of processing her feelings.

I am reminded of the intergeneration nature of her trauma of Apartheid. All three generations have been subject to the dehumanizing system of government. I am reminded of the concept of telescoping of generations (Faimberg, 2005b) in relation to intergenerational transmission of parental trauma which encompasses a process whereby at least two, sometimes three, generations psychically insert into the next generation narcissistic elements of themselves that become an aspect of the new generation's narcissistic personality structure. She remarked that there are always at least two or three generations present in the therapy consulting room, highlighting Sibulelo's therapy of her two previous generations. Each of the two previous generations targeted her to carry some of their unsymbolised ancestral trauma. They become known, as Feldman (2015) observed, only during key pivotal moments in the transference-countertransference matrix when the history of family trauma are revealed.

In the consulting room, Sibulelo brings all her three generations, and as it is a relational, co-creating process, I too bring my own generations of racialized pain. The therapeutic space becomes legacies of intergeneration trauma that merge and blend into both her and my unconscious mind. We are connected in that traumatised space.

\section{Conclusions}

This paper explores intergenerational transmission of parental trauma through projective identification of a black South African female client, called Sibulelo. Such intergenerational trauma is rooted in the experiences of Apartheid. Sibulelo had unknowingly identified with the memories and experiences of her parents and grandparents to such an extent that she felt she was no longer living her own life (dis-located in time and space, as if she was living outside of herself, unplugged from the flow of life. Her successes in life were an unconscious compliance of their expectations. The experience of a dead thing and the alien within speaks again to the projective identification of the parental disavowal in that unwanted visitors to her unconscious mind were inserted into her, dictating, and shadowing her life's possibilities so that she felt her "life had taken on a shape and form she cannot understand". This case confirms some of the existing research, referred to earlier, that indicates that such clients are haunted by the ghosts of unsymbolized parental trauma.

During the therapy process, Sibulelo needed me to know that "I am not what you think you see". The wellgroomed, rich black woman is not what I think. Behind all the wealth, the high heels, the expensive designer clothes, the beautiful face, lay an ocean of pain. Such pain needs to be seen and recognised. I did eventually see her pain. What she saw reflected in my subjectivity was my seeing this pain, and thus my recognition of her pain, of her subjectivity. I am borrowing from Winnicott's (1971) idea that what the baby sees reflected in the mothers eyes is what the mother sees, thus giving a sense of existence, of being. This concept links to the notion of finding oneself in and through the other. There is an old African saying of we-selves meaning that we are selves because of the we/the other. This is essentially the same idea grounded in the notion of intersubjectivity (Benjamin, 2004, 2009) which says that the self is found in another person. In working with intergeneration transmission of parental trauma through projective identification, this action of being seen is pivotal to the process; it is about the we of the dyad, the functionality of inter-subjectivity, and what the other does in relation to the one suffering. The other bears the pain, not just witnesses it. Bearing the pain is seeing the pain. In the shared we-selves it allows for a reclaiming of one's life again, in and through the other, after living in the shadows of parental disavowal. Without being seen (Benjamin, 2004, 2009), and thus without the other, there are only endless cycles of repetition of trauma.

Finally, the unconscious inter-subjectivity in the context of intergenerational transmission of parental trauma is particularly powerful when it represents the same psycho-dynamics of historical racialized trauma of oppressor-oppressed. This case illustrates how the analytical material developed because of this constellation of blackwhite in relation to historical racial oppression. Without my whiteness, it is possible that Sibulelo may not have reached some of the places and spaces in the process that she did. In other words, what emerged in Sibulelo's therapy was because I was white and she was black. However, more can be said about my whiteness. Sibulelo had chosen me, and as such, she made assumptions about me, and about my whiteness. While one correct assumption was that I was a whitie with a difference, and could work with black clients and their racialized past, another erroneous assumption was her equating my whiteness with badness, with Apartheid, with oppression/oppressor. The fact is that I am not a part of this racialized South African history. I don't defend myself, however, or my whiteness, in therapy because black clients' may need to create in me the bad object (Klein, 1946) that they need. They may need to project onto my whiteness all the rage and demons that have haunted them. This is what is meant by the idea that some of this analytical material developed because of my whiteness and all that it means in the minds of black clients like Sibulelo.

While it is overly narcissistic to claim that she was healed because I was white, it can be noted that this type 
of racial dynamic (mirroring the past dynamics of oppressor-oppressed) contributed something to the interruption of cycles of black intergenerational trauma. We are reminded that if left unprocessed and uninterrupted, such intergenerational trauma perpetuates itself (Mangassarian, 2016; Matz et al., 2015). If there is no interruption of the cycles of intergenerational trauma, and therefore no symbolization, it becomes an unconscious familial compulsion to repeat. Freud (1920) identified this human pattern of repetition and termed it the repetition compulsion. Freud described this idea as the unconscious tendency to repeat life experiences, a pattern of re-enactment of the past in the present so that nothing is new. Moreover, this therapy case highlights the idea that as a traumatised family living within a bruised culture of intergenerational transmission of trauma, such repetition of trauma becomes a cultural compulsion to repeat what has not been spoken or named.

\section{References}

Abraham, N., \& Torok, M. (1994). The shell and the kernel (N. Rand, Trans.). Chicago: University of Chicago Press.

Anisfeld, L., \& Richards, A. D. (2000). The replacement child: Variations on a theme in history and psychoanalysis. Psychoanalytic Study of the Child, 55, 301-318.

Aron, L. (1996). A meeting of minds: Mutuality in psychoanalysis. Hillsdale, NJ: The Analytic Press.

Baranger, M., \& Baranger, W. (2008). The analytic situation as a dynamic field. International Journal of Psychoanalysis, 89, 795-826.

Bartlett, B. (2017). Time-soaked: How trauma submerges in and out of time. Psychoanalytic Dialogues, 27, 241-254.

Benjamin, J. (2004). Beyond doer and done to: An intersubjective view of thirdness. The Psychoanalytic Quarterly, 73, 5-46.

Benjamin, J. (2009). A relational psychoanalysis perspective on the necessity of acknowledging failure in order to restore the facilitating and containing features of the intersubjective relationship (the shared third). The International Journal of Psychoanalysis, 90, 441-462.

Bergman, M.S. \& Jucovy, M.E. (Eds.). (1982). Generations of the Holocaust. New York: Basic Books.

Bion, W. R. (1957). The differentiation from the psychotic to the non-psychotic personalities. In Second thoughts (pp. 4364). London: Heinemann.

Bion, W. R. (1962). A theory of thinking. In Second thoughts (pp. 110-119). London: Heinemann.

Bohleber, W. (2007). Remembrance, trauma and collective memory: The battle for memory in psychoanalysis. International Journal of Psychoanalysis, 88, 329-52.

Brothers, D. (2014). Traumatic attachments: Intergenerational trauma, dissociation, and the analytic relationship. International Journal of Psychoanalytic Self Psychology, 9, 3-15.

Connolly, A. (2011). Healing the wounds of our fathers: Intergenerational trauma, memory, symbolization and narrative. Journal of Analytical Psychology, 56, 607-626.

Danieli, Y. (1998). (Ed.) International handbook of multigenerational legacies of trauma. New York: Plenum.

Eigen, M. (1981). The area of faith in Winnicott, Lacan and Bion. The International Journal of Psychoanalysis, 62, 413-433.
Eshel, O. (1998). Black holes, deadness and existing analytically. International Journal of Psychoanalysis, 79, 1115-1130.

Faimberg, H. (2005a). 'Listening to listening': An approach to the study of narcissistic resistances in the telescoping of generations. Routledge (pp. 19-30). London, UK: The New Library of Psychoanalysis.

Faimberg, H. (2005b). The telescoping of generations: A genealogy of alienated identifications in the telescoping of generations listening to the narcissistic links between generations. London, UK: Routledge.

Feldman, M. (2015). Ghost stories: Transgenerational trauma and witnessing in analyst and analysand. Psychoanalytic Dialogues, 25, 600-613. doi: 10.1080/10481885.2015.1077050

Ferenczi, S. (1988). The clinical diary. [Original work published 1932]. Cambridge, MA: Harvard University Press.

Freud, S. (1920). Beyond the pleasure principle. In J. Strachey (Ed.), The standard edition of the complete psychological works of Sigmund Freud, Volume 18 (pp. 7-64). London, UK: Hogarth Press.

Garon, J. (2004). Skeletons in the closet. International Forum of Psychoanalysis, 13, 84-92.

Gerson, S. (2009). When the third is dead: Memory, mourning, and witnessing in the aftermath of the Holocaust. International Journal of Psychoanalysis, 90, 1341-1357.

Goldstein, W. N. (1991). Clarification of projective identification. American Journal of Psychiatry, 148(2), 153-161.

Grotstein, J. (1981). Splitting and projective identification. Northvale, NJ: Jason Aronson.

Grotstein, J. (2005). Projective transidentification: An extension of the concept of projective identification. International Journal of Psychoanalysis, 86, 1051-1069.

Jung, C. G. (1934). The meaning of psychology for modern man. In Collected Works (Vol. 10). Princeton, NJ: Princeton University Press.

Kestenberg, J. (1982). A meta-psychological assessment based on an analysis of a survivor's child. In M.S. Bergman \& M.E. Jucovy (Eds.), Generations of the holocaust. New York: Basic Books.

Klein, M. (1946). Notes on some schizoid mechanisms. International Journal of Psychoanalysis, 27, 99-110.

Knight, Z. G. (2013). Black client, White therapist. Working with race in psychoanalytic psychotherapy in South Africa. International Journal of Psychoanalysis, 94, 17-31.

Knight, Z. G. (2017). 'If I leave home, who will take care of mum?' Intergenerational transmission of parental trauma through projective identification, The Scandinavian Psychoanalytic Review, 40, 2, 119-128. doi: 10.1080/01062301. 2018.1436217

Kogan, I. (2002). "Enactment" in the lives and treatment of Holocaust survivors' offspring. Psychoanalytic Quarterly, 71, 251-272.

Levine, H. B. (1982). Toward a psychoanalytic understanding of children of survivors of the Holocaust. Psychoanalytic Quarterly, 51, 70-92.

Mangassarian, S.L. (2016). 100 years of trauma: The Armenian Genocide and intergenerational cultural trauma. Journal of Aggression, Maltreatment \& Trauma, 25 (4), 371-381 doi: 10.1080/10926771.2015.1121191

Matz, D., Vogel, E., Mattar, S. \& Montenegro, H. (2015). Interrupting Intergenerational Trauma: Children of Holocaust Survivors and the Third Reich. Journal of Phenomenological Psychology, 46, 185-205.

Muhlegg, M. (2016). Projective identification in the intergener- 
ational transmission of unsymbolized parental trauma: An adoptee's search for truth. Canadian Journal of Psychoanalysis, 2, 51-73.

Ogden, T. H. (1979). On projective identification. International Journal of Psychoanalysis, 60, 357-372.

Ogden, T. H. (1986). The matrix of the mind: Object relations and the psychoanalytic dialogue. Northvale, NJ: Jason Aronson.

Ogden, T. H. (1997). Reverie and interpretation: Sensing something human. Northvale, NJ: Jason Aronson.

Ogden, T. H. (2004). On holding and containing, being and dreaming. The International Journal of Psychoanalysis, 85, 1349-1364.

Racker, H. (1957). The meanings and uses of countertransference. Psychoanalytic Quarterly, 26, 303-357.

Rapoport, E. (2011). Growing up in the shadow of the Holocaust: A psychoanalyst addresses intergenerational trauma in her family. Issues in Psychoanalytic Psychology, 33, 43-49.

Roitman, Y. (2017). Intergenerational Transmission of Violence: Shattered Subjectivity and Relational Freedom. Psychoana- lytic Social Work, 24(2), 144-162. doi: 10.1080/15228878. 2017.1369439

Searles, H. F. (1979). Countertransference and related subjects. New York: International Universities Press.

Spillius, E., \& O'Shaughnessy, E. (2012). Projective identification: The fate of a concept. London: Routledge.

Tedeschi, R. G., \& Calhoun, L. G. (2004). Posttraumatic growth: Conceptual foundation and empirical evidence. Philadelphia, PA: Lawrence Erlbaum Associates.

Volkan, V. (1997). Bloodlines: From ethnic pride to ethnic terrorism. Boulder, CO: Westview.

Vollhadt, J. R., \& Bilewicz, M. (2013). After the genocide: Psychological perspectives on victim, bystander, and perpetrator groups. Journal of Social Issues, 69(1), 1-15. doi: 10.1111/josi.12000

Winnicott, D. (1971). Playing and reality. London: Routledge.

Zinner, J., \& Shapiro, R. (1972). Projective identification as a mode of perception and behavior in families of adolescents. International Journal of Psychoanalysis, 53, 523-530. 